\title{
Phylogenetic resolution and habitat specificity of members of the Photobacterium phosphoreum species group
}

Jennifer C. Ast and Paul V. Dunlap*

Department of Ecology and Evolutionary Biology,

University of Michigan, Ann Arbor, MI 48109, USA.

\section{Summary}

Substantial ambiguity exists regarding the phylogenetic status of facultatively psychrophilic luminous bacteria identified as Photobacterium phosphoreum, a species thought to be widely distributed in the world's oceans and believed to be the specific bioluminescent light-organ symbiont of several deep-sea fishes. Members of the P. phosphoreum species group include luminous and non-luminous strains identified phenotypically from a variety of different habitats as well as phylogenetically defined lineages that appear to be evolutionarily distinct. To resolve this ambiguity and to begin developing a meaningful knowledge of the geographic distributions, habitats and symbiotic relationships of bacteria in the $P$. phosphoreum species group, we carried out a multilocus, fine-scale phylogenetic analysis based on sequences of the 16S rRNA, gyrB and luxABFE genes of many newly isolated luminous strains from symbiotic and saprophytic habitats, together with previously isolated luminous and non-luminous strains identified as $P$. phosphoreum from these and other habitats. Parsimony analysis unambiguously resolved three evolutionarily distinct clades, phosphoreum, iliopiscarium and kishitanii. The tight phylogenetic clustering within these clades and the distinct separation between them indicates they are different species, P. phosphoreum, Photobacterium iliopiscarium and the newly recognized 'Photobacterium kishitanii'. Previously reported non-luminous strains, which had been identified phenotypically as $\boldsymbol{P}$. phosphoreum, resolved unambiguously as $P$. iliopiscarium, and all examined deep-sea fishes (specimens of families Chlorophthalmidae, Macrouridae, Moridae, Trachichthyidae and Acropomatidae) were found to harbour 'P. kishitanii', not

Received 14 January, 2005; revised 27 April, 2005; accepted 28 April, 2005. *For correspondence. E-mail pvdunlap@umich.edu; Tel. (+1) 734615 9099; Fax (+1) 7347630544.
P. phosphoreum, in their light organs. This resolution revealed also that ' $P$. kishitanii' is cosmopolitan in its geographic distribution. Furthermore, the lack of phylogenetic variation within ' $P$. kishitanii' indicates that this facultatively symbiotic bacterium is not cospeciating with its phylogenetically divergent host fishes. The results of this fine-scale phylogenetic analysis support the emerging view that bacterial species names should designate singular historical entities, i.e. discrete lineages diagnosed by a significant divergence of shared derived nucleotide characters.

\section{Introduction}

Photobacterium phosphoreum is a luminous bacterium that appears to be widely distributed in the world's oceans and to occur in a variety of marine habitats. Strains of this species, assigned various names in the past (Skerman et al., 1980; Euzeby, 2005), were first isolated more than 100 years ago, by Cohn (1878), by Beijerinck (1889) from seawater, and possibly earlier by others from the surfaces of fish (Beijerinck, 1889). Strains identified as $P$. phosphoreum have been reported also from surfaces of other marine animals, intestinal contents of fish, coastal and open-ocean seawater and from bioluminescent symbiosis with fishes (Baumann and Baumann, 1981, 1984; Hastings and Nealson, 1981; Haygood, 1993; Dunlap and Kita-Tsukamoto, 2001). As a bioluminescent symbiont, P. phosphoreum is thought to colonize light organs of a taxonomically wide array of deep-sea fishes; members of six families of teleosts, representing four orders, i.e. Opisthoproctidae (Osmeriformes), Chlorophthalmidae (Aulopiformes), Macrouridae, Steindachneriidae and Moridae (Gadiformes), and Trachichthyidae (Beryciformes), have been reported to harbour symbiotic luminous bacteria identified as or believed to be P. phosphoreum (Kishitani, 1930; Yasaki and Haneda, 1935; Haneda, 1951, 1957; Haneda and Yoshiba, 1970; Hendrie et al., 1970; Singleton and Skerman, 1973; Herring, 1975; Reichelt et al., 1976; Herring and Morin, 1978; Ruby and Morin, 1978; Somiya, 1981; Herring, 1982; Kuwae et al., 1982; Haygood et al., 1992; Vydryakova et al., 1995; Ast and Dunlap, 2004). As a facultative psychrophile, P. phosphoreum may be specifically adapted to symbiosis with these 
fishes, which generally occur in cold meso-pelagic and bentho-pelagic habitats (Hastings and Nealson, 1981; Haygood, 1993; Dunlap and Kita-Tsukamoto, 2001).

Meaningful knowledge of the distribution of $P$. phosphoreum in the marine environment, the habitats it colonizes and its symbiotic relationships with deep-sea fishes requires an unambiguous species diagnosis. However, substantial ambiguity exists regarding the phylogenetic status of facultatively psychrophilic luminous bacteria identified phenotypically as P. phosphoreum; a group of two or possibly more apparently different bacteria currently are referred to as $P$. phosphoreum. Early phenotypic identifications and more recent studies that have included 16S rRNA gene sequence data have noted differences between the type strain, ATCC $11040^{\top}$, and other strains placed in P. phosphoreum and have indicated the presence of subgroups within P. phosphoreum (Hendrie et al., 1970; Reichelt and Baumann, 1973; Singleton and Skerman, 1973; Dalgaard et al., 1997; Budsberg et al., 2003; Ast and Dunlap, 2004). Furthermore, an apparently non-luminous bacterium, Photobacterium iliopiscarium, which is similar phenotypically to P. phosphoreum, has been described from intestines of cold-water fishes (Onarheim and Raa, 1990; Onarheim et al., 1994; Urakawa et al., 1999). The similarity between P. iliopiscarium and $P$. phosphoreum has led the separate species status of $P$. iliopiscarium to be questioned, and some authors have placed otherwise phenotypically similar luminous and non-luminous strains together in $P$. phosphoreum (Dalgaard et al., 1999; Flodgaard et al., 2005). Adding to this complexity, a new clade of facultatively psychrophilic luminous bacteria, the kishitanii clade, was identified recently as closely related to but phylogenetically distinct from $P$. phosphoreum ATCC $11040^{\top}$ and $P$. iliopiscarium ATCC $51760^{\top}$. Grouped in the kishitanii clade are certain strains previously identified as $P$. phosphoreum, including some bioluminescent symbionts of deep-sea fishes (Dunlap and Ast, 2005); at present, ATCC $11040^{\top}$ apparently stands alone as the sole confirmed representative of the $P$. phosphoreum lineage. The taxonomic confusion surrounding $P$. phosphoreum, which limits understanding of the habitats, geographic distributions and symbiosis of this species, exemplifies a fundamental problem in bacterial systematics: how to recognize and diagnose as separate species bacteria that are phenotypically similar but evolutionarily distinct.

In this report, we describe a multilocus phylogenetic analysis based on sequences of the 16S rRNA, gyrB and lUxABFE genes of many newly isolated and previously reported strains of the $P$. phosphoreum group. The finescale phylogenetic resolution afforded by this analysis distinguishes three evolutionarily distinct, robustly supported lineages: P. phosphoreum, P. iliopiscarium and a newly recognized species, 'Photobacterium kishitanii'.
Furthermore, this resolution demonstrates that ' $P$. kishitanii', not P. phosphoreum, is the specific bioluminescent symbiont of many deep-sea fishes.

\section{Results}

Resolution of P. phosphoreum and 'P. kishitanii' as separate species

In a recent phylogenetic analysis of luminous bacteria thought to be P. phosphoreum, we identified only ATCC $11040^{\top}$ of the strains examined as a bona fide member of this species; all other strains were identified as members of a distinct but previously unrecognized clade, the kishitanii clade (Dunlap and Ast, 2005). The apparent uniqueness of ATCC $11040^{\top}$ led us to isolate several additional strains of luminous bacteria from the skin of fish, the P. phosphoreum type strain habitat (see Experimental procedures), with which to test the phylogenetic status of this species in relation to the kishitanii clade. Two possible outcomes were anticipated, that newly isolated strains would cluster with ATCC $11040^{\top}$ or with the kishitanii clade, which would confirm the presence of two evolutionarily distinct entities, or that a gradation of strains would be found, which would link ATCC $11040^{\top}$ with the kishitanii clade in a phylogenetic continuum.

All of the eight tested samples of fish, which represented various species and were collected from a variety of locations in the Pacific Ocean and the Atlantic Ocean (Table 1), yielded luminous bacteria; two or three strains were isolated from each fish sample. Simultaneous analysis of the 16S rRNA, gyrB and luxABFE genes demonstrated that the majority of these fish skin (FS) isolates (14 of 18 strains) clustered with ATCC $11040^{\top}$ (Fig. 1) forming a coherent clade, designated here the phosphoreum clade. The four other FS strains were resolved to the kishitanii clade. Previously, NCIMB 844 was the only member of the kishitanii clade identified from the skin of fish; all other strains of this clade had been obtained from the light organs of deep-sea fishes (Dunlap and Ast, 2005).

To further test the apparent distinction between the phosphoreum and kishitanii clades, we next re-evaluated the phylogenetic status of strains recently isolated from migrating salmon from Alaska. The Alaska (AK) strains had been identified as $P$. phosphoreum by a set of phenotypic traits that distinguishes the known species of luminous bacteria (Budsberg et al., 2003); these traits, however, apparently do not distinguish ATCC $11040^{\top}$ from members of the kishitanii clade, e.g. NZ-11D. Phylogenetic analysis of combined 16S rRNA, gyrB and luxABFE gene sequences resolved all of the tested $A K$ strains to the phosphoreum clade, with robust Bremer and jackknife re-sampling support (Fig. 1). 


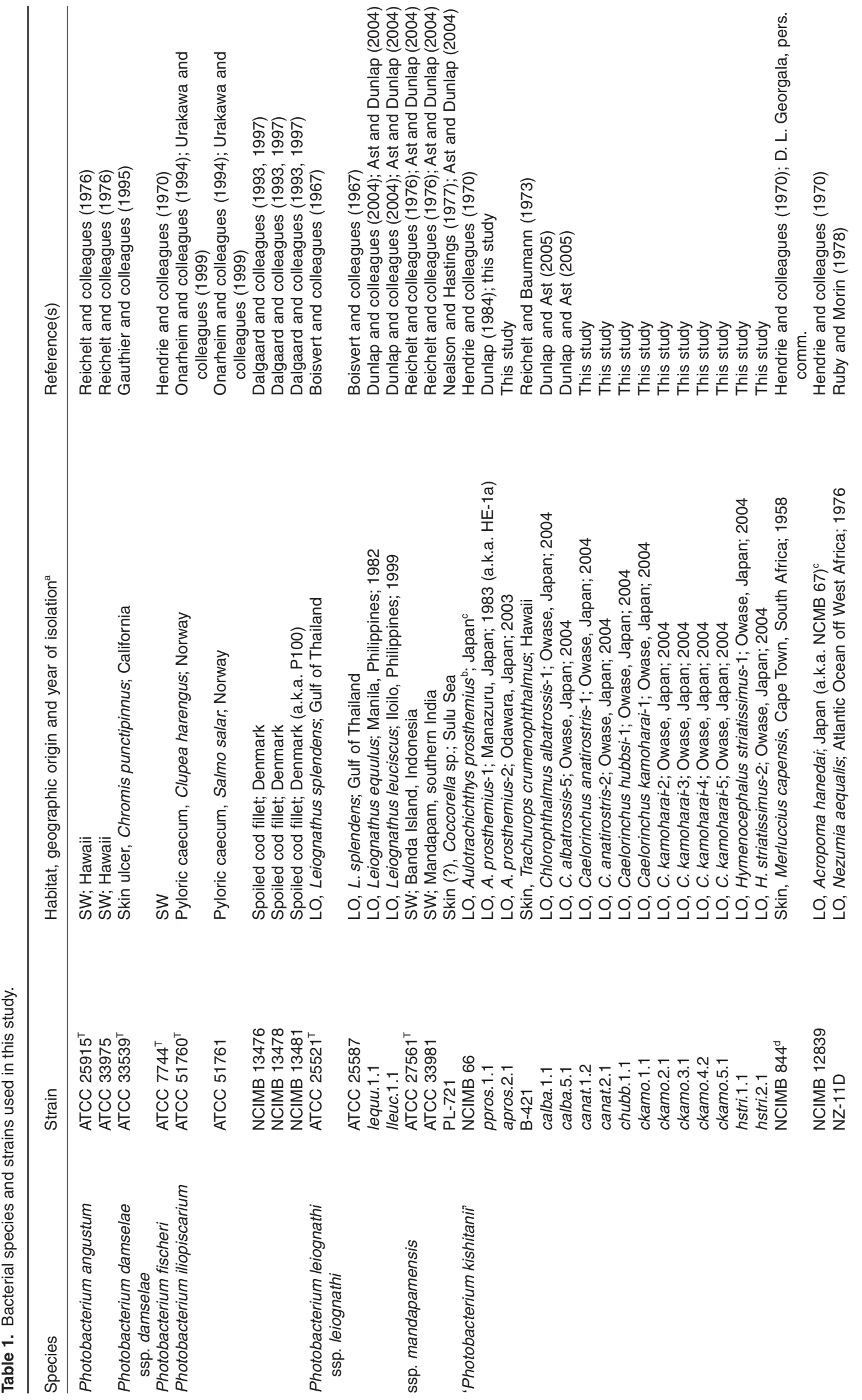




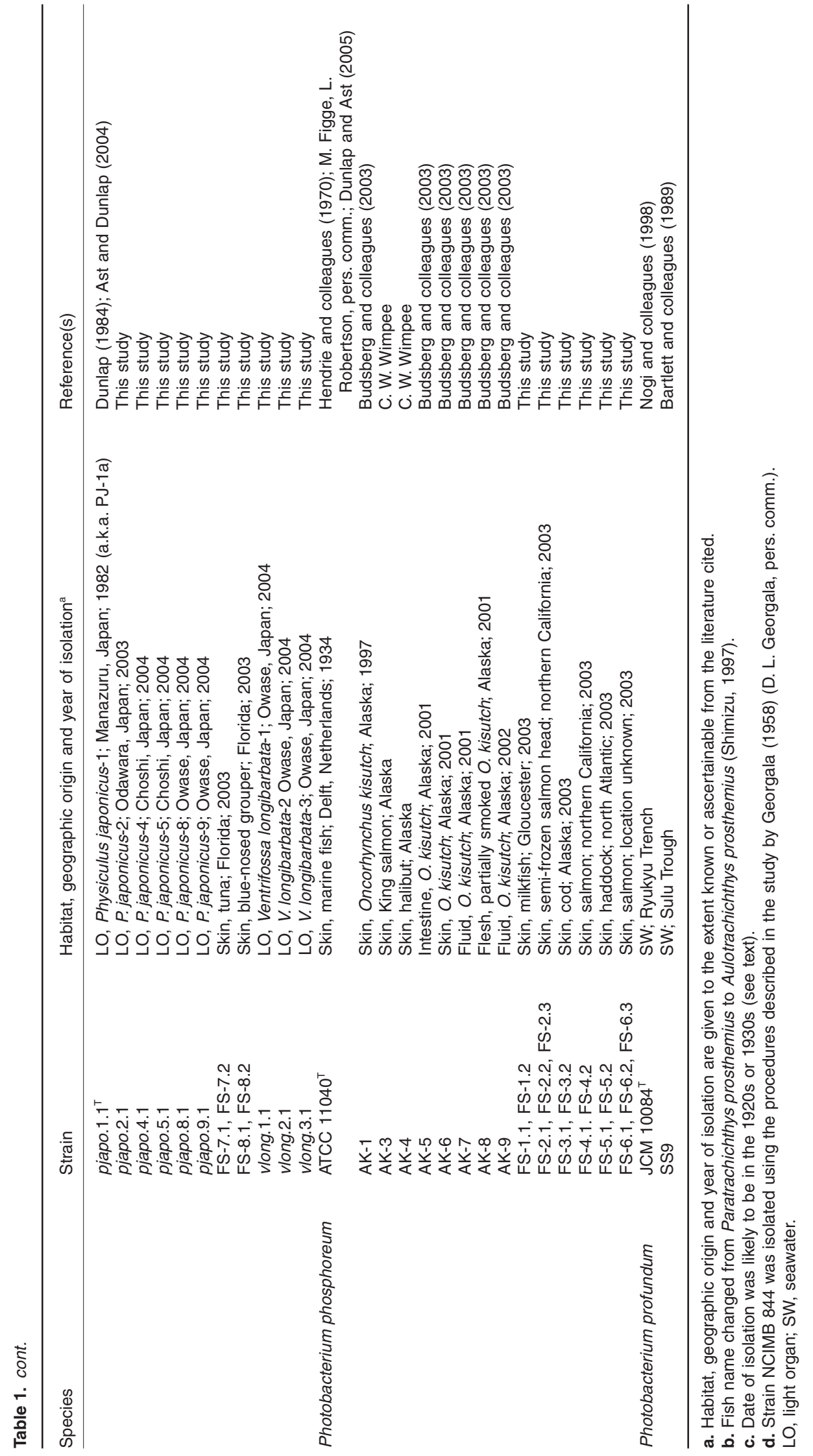




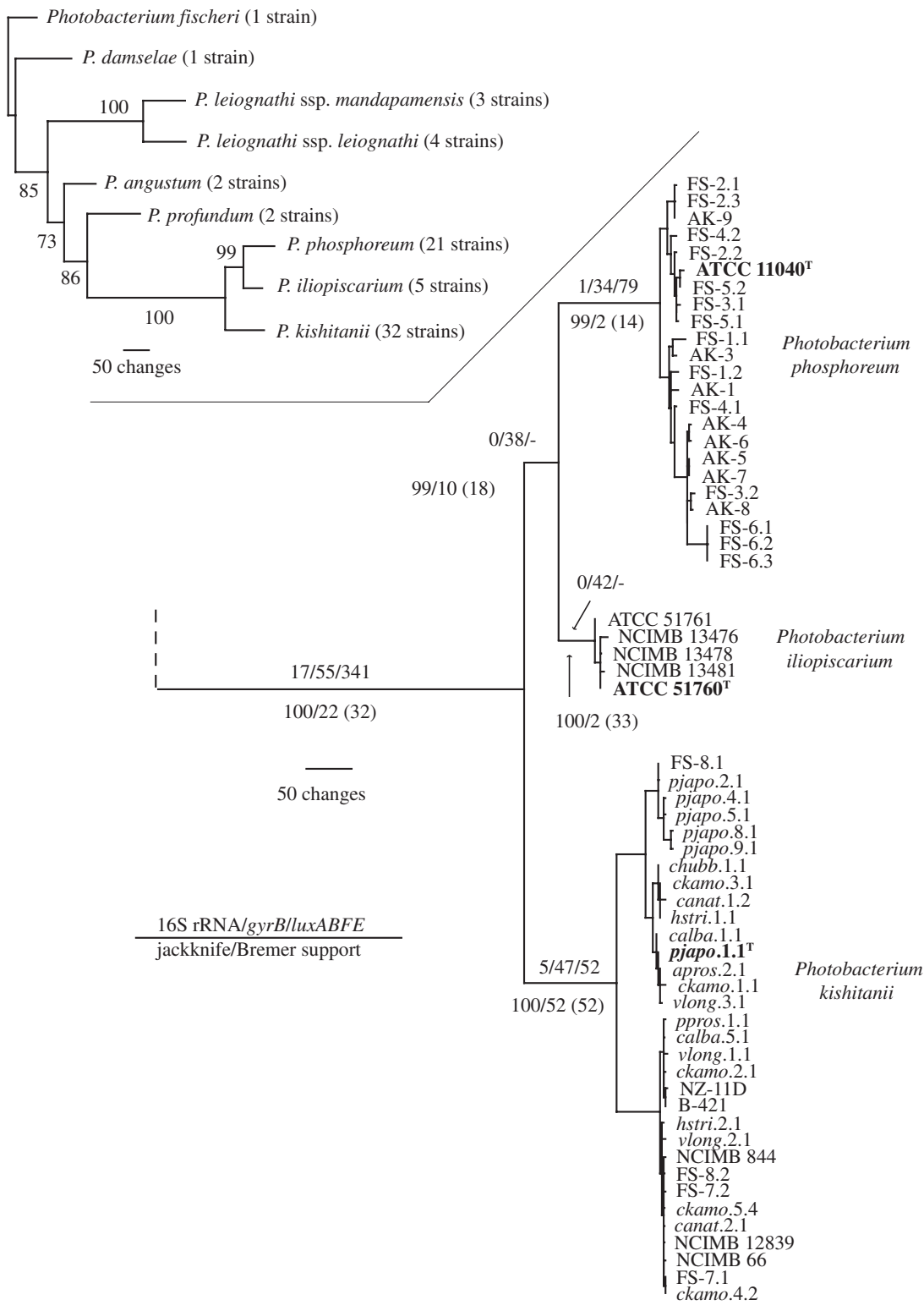

Fig. 1. Phylogeny of Photobacterium (insert at upper left; numbers represent jackknife resampling values) and detail of the P. phosphoreum group (main figure), based on simultaneous analysis of $16 \mathrm{~S}$ rRNA, gyrB and IUXABFE. Tree 1 of 2688 most parsimonious trees is shown (length $=3136$; overall consistency index $=0.75$; overall retention index $=0.94$ ). . The data set was also analysed without AK-1 and AK-9, which resulted in substantially fewer most parsimonious trees (144) with a slightly shorter length (length $=3128$ ). Numbers above branches represent the steps each locus (16S rRNA, gyrB and luxABFE) contributed to branch length. Note that the $16 \mathrm{~S}$ rRNA gene contributed several steps (17 steps) to the separation of the $P$. phosphoreum group from the rest of Photobacterium, but contributed few steps (0-1 step) to the branches separating $P$. phosphoreum and $P$. iliopiscarium; the sequences of ' $P$. kishitanii' strains differed slightly (5 steps) from those of $P$. phosphoreum and $P$. iliopiscarium. In contrast, the gyrB gene contributed substantially and roughly equally to the separation of all branches. Numbers below branches represent jackknife re-sampling values and Bremer support values. Omitting strains AK-1 and AK-9 from the analysis (see Experimental procedures) substantially improved the Bremer support values (numbers in parentheses). AK-1 and AK-9 were omitted from jackknife analysis, and therefore these two strains are not included in the insert at upper left. Type strains are in boldface.
These results establish the phosphoreum and kishitanii clades as evolutionarily distinct bacterial lineages. All the new or previously isolated luminous strains tested here resolved unambiguously to either the phosphoreum clade, clustering closely with ATCC $11040^{\top}$, or to the kishitanii clade. A phylogenetic continuum was not observed. The large number of strains examined and the strong support for the separation of these two clades (Fig. 1) indicate that they should be considered separate species, P.phosphoreum, represented by ATCC $11040^{\top}$, and ' $P$. kishitanii' respectively. The species name kishitanii recognizes the Japanese scientist Teijiro Kishitani, who first isolated luminous bacteria from the light organ of the deep-sea fish, Physiculus japonicus (Gadiformes: Moridae) (Kishitani, 1930; Dunlap and Ast, 2005). Strain pjapo.1.1 $1^{\top}$, which was isolated from a specimen of $P$. japonicus (Table 1) and which is representative of this species, is designated as the type strain of ' $P$. kishitani'. The fish specimen from which pjapo.1.1 $1^{\top}$ was isolated, DA01, has been retained for taxonomic reference. Strain pjapo.1.1 $1^{\top}$ has been deposited at the American Type Culture Collection as ATCC BAA-1194.

Light-organ symbiosis as a habitat specific for 'P. kishitanii'

The ability to distinguish P.phosphoreum from ' $P$. kishitanii' placed us in a position to ask if $P$. phosphoreum actually occurs in light-organ symbiosis with deep-sea fishes. Previously, P. phosphoreum was believed to be the exclusive bioluminescent symbiont of many deep-sea 
Table 2. Deep-sea fishes harbouring ' $P$. kishitanii' as light-organ symbiont. $^{\text {a }}$

\begin{tabular}{|c|c|c|}
\hline Order & Family & Species \\
\hline Aulopiformes & Chlorophthalmidae & Chlorophthalmus albatrossis \\
\hline Gadiformes & Macrouridae & $\begin{array}{l}\text { Caelorinchus anatirostris } \\
\text { Caelorinchus hubbsi } \\
\text { Caelorinchus kamoharai } \\
\text { Hymenocephalus striatissimus } \\
\text { Nezumia aequalis } \\
\text { Ventrifossa longibarbata }\end{array}$ \\
\hline & Moridae & Physiculus japonicus \\
\hline Beryciformes & Trachichthyidae & Aulotrachichthys prosthemius ${ }^{b}$ \\
\hline Perciformes & Acropomatidae & Acropoma hanedai \\
\hline
\end{tabular}

a. The light-organ symbiont of Opisthoproctis grimaldii (Osmeriformes: Opisthoproctidae) and of steindachneriids (Gadiformes) and also might be 'P. kishitanii' (see text).

b. Name changed from Paratrachichthys prosthemius to Aulotrachichthys prosthemius (Shimizu, 1997).

fishes, but the validity of this belief was brought into question by the recent identification of the symbionts of C. albatrossis (Aulopiformes: Chloropthalmidae) and certain other fishes as members of a phylogenetically distinct clade, the kishitanii clade (Dunlap and Ast, 2005) (i.e. ' $P$. kishitanii'). We also sought to test the host range of ' $P$. kishitanii', by sampling a more extensive array of luminous fishes.

For this analysis, bacterial strains from the light organs of 26 specimens of deep-sea fishes, representing 10 species in five families of four teleost orders (Tables 1 and 2), were examined. Included were strains isolated previously by others from light organs of deep-sea fishes and reported as $P$. phosphoreum (Table 1). Phylogenetic analysis based on the 16S rRNA, gyrB and luxABFE genes identified each of these strains, without exception, as P. kishitanii (Fig. 1). Despite the number of strains tested, the diversity of the host animals examined and the various collection dates and collection locations, no strain of $P$. phosphoreum was found in light-organ symbiosis. These results indicate that ' $P$. kishitanii', not $P$. phosphoreum, is the specific bioluminescent symbiont of these deep-sea fishes.

Identification of 'non-luminous P. phosphoreum' strains as P. iliopiscarium

The ability to resolve P. phosphoreum and ' $P$. kishitanil' also allowed us to examine the relationship of these two species with the third member of this group, $P$. iliopiscarium. The separate species status of $P$. iliopiscarium has been questioned (Dalgaard et al., 1999), but analysis of the gyrB gene sequences of the type strains of P. phosphoreum and P. iliopiscarium, ATCC $11040^{\top}$ and ATCC $51760^{\top}$, respectively, supports a species-level separation (Dunlap and Ast, 2005). However, the limited number of strains identified as P. iliopiscarium has provided little material with which to test the robustness of this separation. To address this problem, we first examined a second available strain of P. iliopiscarium, ATCC 51761, isolated like ATCC $51760^{\top}$ from the pyloric caecum of a marine, cold-water fish (Onarheim et al., 1994). Based on 16S rRNA and gyrB gene sequence analysis, ATCC 51761 was found to be very closely related to ATCC $51760^{\top}$ (Fig. 1).

Next, we tested the phylogenetic status of strains reported as $P$. phosphoreum but isolated from spoiled cod stored at low temperature (i.e. 'non-luminous P. phosphoreum') (Dalgaard et al., 1993, 1997; Flodgaard etal., 2005). The phenotypic similarity between P. phosphoreum and P. iliopiscarium (Dalgaard et al., 1999) suggested to us that non-luminous strains identified as $P$. phosphoreum from this habitat instead might be members of $P$. iliopiscarium. An attempt to isolate such bacteria from a sample of frozen vacuum-packed cod fillet incubated in the same way as the fish samples above was not successful; no significant bacterial growth was detected from this sample during 6 days of incubation. Therefore, we examined three strains previously isolated from spoiled cod and identified as P.phosphoreum, NCIMB 13476, NCIMB 13478 and NCIMB 13481. Analysis of the sequences of the 16S rRNA and gyrB genes of these strains revealed them to be essentially identical to ATCC $51760^{\top}$ and ATCC 51761. Very few nucleotide differences were found among the five strains, which formed a tightly clustered clade (Fig. 1). Divergence of these strains from P.phosphoreum and 'P. kishitanii' in the sequence of the 16S rRNA gene, though detectable, was slight (Fig. 1; Dunlap and Ast, 2005), whereas the divergence in gyrB was distinct. The phylogenetic coherence of the spoiled cod isolates with ATCC $51760^{\top}$ and ATCC 51761 demonstrates that they are members of $P$. iliopiscarium, not P. phosphoreum. Furthermore, the jackknife re-sampling and Bremer support values indicate strong support for the separation of $P$. iliopiscarium from its sister species, $P$. phosphoreum, and from the next most closely related species, 'P. kishitanii' (Fig. 1).

\section{Inability to detect lux genes in P. iliopiscarium}

We next tried to identify lux genes in P. iliopiscarium, as a basis for further defining the relationship of this species with P. phosphoreum and 'P. kishitanii'. Although $P$. iliopiscarium is not known to be luminous, and none of the five strains of this species examined here emitted light that could be detected by a sensitive photometer, lack of light production does not necessarily indicate the absence of lux genes (Palmer and Colwell, 1991; Fidopiastis et al., 1999). The close relationship among these three species, strains of two of which are intensely luminescent, suggested that P.iliopiscarium might carry genes for luminescence. 


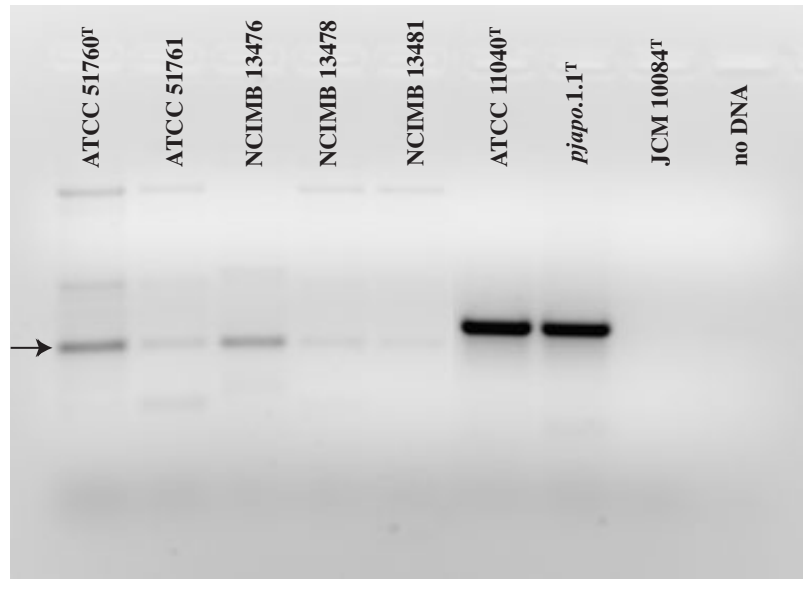

Fig. 2. Test for presence of IuxA in $P$. iliopiscarium. PCR amplification of IUXA was attempted using the general IUXA primers and protocol of Wimpee and colleagues (1991) (Experimental procedures). Lanes: 1, ATCC $51760^{\top}$; 2 , ATCC 51761; 3, NCIMB 13476; 4, NCIMB 13478; 5, NCIMB 13481 (lanes 1-5, P. iliopiscarium); 6, ATCC 11040 ${ }^{\top}$ (P. phosphoreum; luxA positive control); 7, pjapo.1.1' ('P. kishitanii'; luxA positive control); 8 , JCM $10084^{\top}$ (P. profundum, a non-luminous species; negative control); and 9, no DNA (negative control). Arrow at left indicates the spurious, non-luxA amplicon of the five $P$. iliopiscarium strains (see text), which was excised from the gel and sequenced for strains ATCC $51760^{\top}$ and NCIMB 13476 (AY888007 and AY888008 respectively).

To test for the presence of the lux genes, we used polymerase chain reaction (PCR) and attempted to amplify luxA, the gene encoding the $\alpha$-subunit of luciferase, the light-emitting enzyme. Initially, we used primers and a permissive amplification protocol that are effective for amplifying approximately $676 \mathrm{bp}$ of the IuxA gene from all known species of luminous bacteria (Wimpee et al., 1991; Ast and Dunlap, 2004). A weakly abundant PCR product of length similar to that of IuxA was detected for each of the P. iliopiscarium strains (Fig. 2), and sufficient amounts of this product were recovered for ATCC $51760^{\top}$ and NCIMB 13476 for sequencing. The products from ATCC $51760^{\top}$ and NCIMB 13476 were found to be an identical open reading frame of $556 \mathrm{bp}$ (see Experimental procedures; AY888007 and AY888008 respectively). BLAST analysis, however, revealed this sequence to have no meaningful nucleotide or amino acid residue sequence similarity to IUXA.

Therefore, to consider the possibility that specific primers might be more effective for amplifying IuxA from $P$. iliopiscarium, we next tested different sets of primer pairs designed against luxA from related species, specifically, P. phosphoreum (also effective with 'P. kishitanii'), Photobacterium leiognathi and Photobacterium fischeri (Ast and Dunlap, 2004; Dunlap and Ast, 2005), again using the amplification protocol of Wimpee and colleagues (1991). For none of the five strains of P. iliopiscarium, however, was a product of the expected size generated. To test whether an even less stringent amplification protocol might be effective, we used the general luxA primers of Wimpee and colleagues (1991), as well as the primer pair specific for P. phosphoreum and ' $P$. kishitanii', but with an extremely permissive amplification protocol (Experimental procedures). Again, no product of the expected size was generated. Nonetheless, in those cases in which a discernible product of even approximately appropriate size (i.e. between 0.5 and $1 \mathrm{~kb}$ ) was generated, we isolated the product and had it sequenced. None of these products, however, exhibited meaningful nucleotide or amino acid residue sequence similarity to IUXA. We conclude that the five strains of $P$. iliopiscarium examined here lack the lux $A$ gene. The absence of luxA further distinguishes $P$. iliopiscarium from $P$. phosphoreum and 'P. kishitanii', and its absence is consistent with the inability of the five $P$. iliopiscarium strains examined here to produce luminescence.

\section{Discussion}

The results of this study demonstrate that the $P$. phosphoreum species group is composed of three evolutionarily distinct lineages, P.phosphoreum, $P$. iliopiscarium and 'P. kishitanii'. Members of two of these facultatively psychrophilic lineages, P. phosphoreum and ' $P$. kishitanii', represented by the types, ATCC $11040^{\top}$ and pjapo.1.1 $1^{\top}$, respectively, are luminous, whereas the third lineage, P. iliopiscarium, represented by ATCC $51760^{\top}$, is non-luminous and apparently lacks the genes for light production. Photobacterium phosphoreum and P. iliopiscarium have been recognized for some time as distinct (Skerman et al., 1980; Euzeby, 2005), and the results presented here fully support their recognition as valid and separate species. As sister species, $P$. phosphoreum and P. iliopiscarium are more closely related to each other than either is to 'P. kishitanii', which is recognized here as a new species, pending validation of this species epithet. The strongly supported resolution of these lineages is based on a comprehensive taxonomic sampling, combined multilocus analysis of the 16S rRNA, gyrB and luxABFE genes, and examination of a large number of new and previously reported strains isolated at various times and from a variety of habitats and geographic locations. Divergence in the gyrB and luxABFE genes contributed substantially more to the resolution of these three species than the 16S rRNA gene, which highlights the constraints on divergence of the 16S rRNA gene.

In contrast to the resolution presented here, there has been substantial ambiguity in the species composition and correct identification of strains in the P. phosphoreum species group. Representatives of P.phosphoreum, P. iliopiscarium and 'P. kishitanii', e.g. ATCC 11040', NCIMB 13481 and NCIMB 844, respectively, have been 
grouped together as P.phosphoreum in the past, and phenotypic similarity with P.phosphoreum has led the species status of $P$. iliopiscarium to be questioned (Dalgaard et al., 1999). This ambiguity results primarily from reliance on phenetic analysis (i.e. chemotaxonomic traits, morphological characters, mol\% $\mathrm{G}+\mathrm{C}$ ratios and DNAreassociation values) (e.g. Hendrie et al., 1970; Reichelt and Baumann, 1973; Ruby and Morin, 1978; Dalgaard et al., 1997). Phenetic comparisons, however, do not necessarily inform about historical relationships, as demonstrated here, and even when phenotypic analyses are extensive and are combined with 16S rRNA gene sequence data, phylogenetically erroneous conclusions can result (e.g. Dalgaard et al., 1999; Flodgaard et al., 2005). Earlier phylogenetic analyses of this group, based on sequence of the 16S rRNA gene (Onarheim et al., 1994; Urakawa et al., 1999), also failed to detect the differences between these species, due primarily to a limited sampling of strains (see e.g. Hillis, 1998; Graybeal, 1998). It is apparent from the results presented here and elsewhere (e.g. Fox et al., 1992; Roselló-Mora and Amann, 2001, Thompson et al., 2004) that the constraints on divergence of the 16S rRNA gene limit its value for species-level resolution and identification. In contrast, we demonstrate here that a multilocus genotypic approach is effective for distinguishing these phenotypically similar but evolutionarily distinct bacteria. We believe that similar insights into species-level divergence will be revealed also for other bacterial groups, as exemplified by a recent study of Bradyrhizobium (Vinuesa et al., 2005), when sufficient numbers of strains are examined in the context of a comprehensive taxon sampling and using multiple genetic loci that have diverged sufficiently to provide fine-scale phylogenetic resolution.

The five strains of $P$. iliopiscarium examined here apparently lack IuxA. The absence of IuxA in P. iliopiscarium is a major genetic difference from its sister species, $P$. phosphoreum, and from the next most closely related species, ' $P$. kishitanii', the known strains of which are strongly luminescent and therefore apparently bear an intact lux operon. This finding is at variance with an earlier study in which IUxA was reported in strains of P. iliopiscarium (called 'non-luminous P.phosphoreum'; Dalgaard et al., 1999; see also Flodgaard et al., 2005). Because we were unable to detect IuxA from any strain of $P$. iliopiscarium examined, despite the use of various primers and PCR protocols that readily amplify IuxA from $P$. phosphoreum, 'P. kishitanii' and all other species of luminous bacteria, the earlier study appears to be erroneous. Directly testing the results of the earlier study, however, was not possible; the specific strains examined were not indicated, the primers and PCR protocol used were not described, and the putative luxA sequences were not reported.
We hypothesize that presence of the lux genes is an ancestral trait in Photobacterium, given the presence of the lux genes in several other members of this genus (e.g. Dunlap and Kita-Tsukamoto, 2001; Dunlap and Ast, 2005). Therefore, the absence of IuxA in P. iliopiscarium together with the phylogeny reconstructed in this study suggest that, after the divergence of ' $P$. kishitanii' from the ancestral lineage, the lux genes were lost from the lineage that became $P$. iliopiscarium but were retained in the lineage that became P. phosphoreum. A similar loss, involving the luxF gene, has been postulated to mark the evolutionary divergence between the leiognathi and mandapamensis clades of P. leiognathi (Ast and Dunlap, 2004). We note parenthetically here that the extent of nucleotide divergence between the leiognathi and mandapamensis clades in $\operatorname{lu} A B B(F) E$ is substantially greater than that separating P.phosphoreum, P. iliopiscarium and ' $P$. kishitani'; the leiognathi and mandapamensis clades therefore apparently represent separate species, P. leiognathi and 'Photobacterium mandapamensis' respectively.

The ecological distributions of $P$. phosphoreum and $P$. iliopiscarium are very poorly known at this time. Photobacterium iliopiscarium has been identified only from the pyloric caeca of cold-dwelling fishes (Onarheim et al., 1994) and, as reported here, from samples of spoiled cod fish stored under modified atmosphere at low temperature (Dalgaard et al., 1993, 1997). In contrast, P. phosphoreum commonly can be isolated from the skin of marine fish incubated at low temperature (Budsberg et al., 2003; this study), a habitat in which 'P. kishitanii' also occurs. Critical assessment of earlier reports of the incidence of $P$. phosphoreum in various habitats (e.g. Baumann and Baumann, 1981; Dalgaard et al., 1997) is precluded by the previous inability to distinguish this species from ' $P$. kishitanii' and $P$. iliopiscarium. The phylogenetic resolution provided here, however, will permit these species to be distinguished in the future and the extent of their habitat specificity to be defined.

This ecological ambiguity does not extend to the light organ habitat. Despite a concerted effort to identify $P$. phosphoreum in light organs of deep-sea fishes, we found only strains of ' $P$. kishitanii'. Many newly isolated and previously reported strains, from symbiosis with a taxonomically broad sampling of host fishes captured at many different locations, were examined here, and all were found to be members of ' $P$. kishitanii'. These results indicate that ' $P$. kishitanii', not $P$. phosphoreum, is the specific and apparently exclusive bioluminescent symbiont of many different deep-sea fishes. A recent analysis supports this conclusion; over 100 additional strains from other specimens of deep-sea fishes, including strains from several host species not reported here, were examined, and all were found to be 'P. kishitanii' (P.V. Dunlap, J.C. 
Ast, S. Kimura, and A. Fukui, unpublished data). Nonetheless, it is possible that $P$. phosphoreum might occur as the light-organ symbiont of some specimens or of certain species of deep-sea fishes.

The strains of ' $P$. kishitanii' examined here were isolated at very different times over the past $70-80$ years. Strains NCIMB 66 and NCIMB 12839 (a.k.a. NCMB 67), which were deposited with the NCIMB in 1958 (J. Young, pers. comm.), were isolated by $Y$. Yasaki apparently during the 1920s or 1930s (e.g. Yasaki et al., 1926; Yasaki and Haneda, 1935). Other strains were isolated more recently but still many years ago; for example, NCIMB 844 was isolated in 1958 (D. Georgala, pers. comm.), B-421 prior to 1973 (Reichelt and Baumann, 1973), NZ-11D in 1976 (Ruby and Morin, 1978) and pjapo.1.1 $1^{\top}$ and ppros.1.1 in the early $1980 \mathrm{~s}$, whereas several strains examined here were isolated in 2003 and 2004. Despite this span of time, these strains exhibit very little sequence divergence. For example, strain NCIMB 12839 is identical in gyrB and IUXABFE gene sequences to strain canat.2.1, which was isolated in 2004. What does this lack of divergence indicate? One implication is that intraspecific (within-clade) divergence in bacteria does not necessarily occur rapidly. The kishitanii clade appears highly stable phylogenetically over time. A similar tight clustering consistent with phylogenetic stability is seen also in P. phosphoreum, the type strain of which, ATCC $11040^{\top}$, was isolated in 1934, and also for P. iliopiscarium, although the existence of this species was recognized only in the past 10 years (Onarheim et al., 1994; Urakawa et al., 1999). These observations suggest that bacteria, despite their potential for rapid reproduction, do not undergo rapid phylogenetic divergence in nature. Furthermore, the tight clustering of strains within each of these three species contrasts sharply with the divergence in inherited characters that separates them. In other words, $P$. phosphoreum, P. iliopiscarium and ' $P$. kishitanil' are recognizable as evolutionarily discrete entities that diverged in the distant past and that are diagnosable as separate species through the use of an extensive set of shared derived nucleotide characters.

The results of this multilocus, fine-scale analysis also indicate that ' $P$. kishitanii' is cosmopolitan in its biogeographic distribution. A critical factor for defining the species-specific geographic distributions of bacteria in nature is the ability to unequivocally distinguish strains of one species from those of closely related species (e.g. Staley, 1999). Previously however, this level of resolution has not been available for members of the P. phosphoreum species group, and the consequent phylogenetic ambiguity has precluded an understanding of the specific geographic distributions of the members of this group. The fine-scale, species-level resolution provided here, however, reveals that ' $P$. kishitanii' is widely distributed geographically. Strains of this species were isolated from the
Atlantic Ocean, off the coast of West Africa, at Cape Town, South Africa, and off the coast of Florida, as well as from the Pacific Ocean, near Hawaii and at various locations along the coast of Honshu, Japan. No geographic pattern is evident, and even strains that are essentially identical in 16S rRNA, gyrB and luxABFE gene sequences, e.g. FS-8.1 and pjapo.2.1, and FS-7.1 and ckamo.4.2, were isolated from very different locations. Current-driven global mixing of oceanic waters coupled with symbiotic association with many different and actively swimming deepsea fishes presumably account for this cosmopolitan distribution. In the fluid deep-sea environment, where physical barriers to dispersal that could lead to endemism (e.g. Papke et al., 2003; Whitaker et al., 2003) apparently do not exist, a cosmopolitan distribution therefore may be the norm for facultatively symbiotic bacteria. Similarly, $P$. phosphoreum appears to be widely distributed in the Pacific and Atlantic oceans; its wide distribution underscores the apparent importance of oceanic circulation and associations with actively swimming fishes in the distribution of free-living and saprophytic marine bacteria. We believe that multilocus, fine-scale phylogenetic analysis holds great promise for opening up questions of the biogeographic distributions of bacteria in nature.

The phylogenetic resolution presented here also provides insight into the question of cospeciation between ' $P$. kishitanii' and deep-sea fishes and the broader issue of bacterial specificity in bioluminescent symbiosis. Strains of this bacterium have been isolated from lightorgan symbiosis with 15 species of fishes, representing five families in four teleost orders, Chlorophthalmidae (Aulopiformes), Macrouridae and Moridae (Gadiformes), Trachichthyidae (Beryciformes) and Acropomatidae (Perciformes) (Table 2; P.V. Dunlap, J.C. Ast, S. Kimura, and A. Fukui, unpublished data). The host range of ' $P$. kishitanii' apparently extends also to a sixth family, Opisthoproctidae, in a fifth order, Osmeriformes, based on the sequence identity of the 16S rRNA genes of strain Og61, from Opisthoproctis grimaldii, with ' $P$. kishitani' NZ-11D (Haygood et al., 1992; Dunlap and Ast, 2005), and it might extend to a seventh family, Steindachneriidae (Gadiformes). The evolutionary divergences between these different host fish orders, members of which are symbiotic with a single, well-resolved bacterial species, is prima facie evidence against symbiont-host cospeciation (Dunlap, 2004). Furthermore, ' $P$. kishitanii' exhibits little within-species diversity, and phylogenetically very similar strains colonize fish in different orders. Therefore, the specificity of ' $P$. kishitanii' for these fishes does not appear to result from parallel host-symbiont evolutionary divergence, i.e. cospeciation.

What does the situation with ' $P$. kishitanii' tell us about the broader issue of the patterns of bacterial species specificity in bioluminescent symbiosis? One informative 
factor is the wide host range of ' $P$. kishitanii', as noted above, which contrasts with that of other symbiotic luminous bacteria. Another informative factor is differences in host habitat. Photobacterium leiognathi, for example, is symbiotic with a single clade of fishes, Leiognathidae (Perciformes), found in shallow, warmer waters, and with some shallow-dwelling loliginid squids (Dunlap and Kita-Tsukamoto, 2001; Dunlap et al., 2004; Sparks and Dunlap, 2004). Noteworthy in this regard is the fish, Acropoma hanedai (Acropomatidae). Although acropomatids are, like leiognathids, members of Perciformes and therefore are more closely related to leiognathids than to chlorophthalmids, macrourids, morids, or trachichthyids, $A$. hanedai is a cold, deep-dwelling fish, and it harbours the facultatively psychrophilic luminous bacterium ' $P$. kishitanii' as its light-organ symbiont. Therefore, host phylogeny does not correlate with and apparently is not determinative of bacterial specificity. What the symbiotic hosts of ' $P$. kishitanii' have in common, despite their wide phylogenetic divergences, is the deep sea; all are cold, deep-dwelling fishes. We propose therefore as originally suggested by Hastings and Nealson (1981), that environmental congruence, i.e. the overlap between the temperatures at which the different host fishes naturally occur and the effective growth temperature ranges of the different species of symbiotic luminous bacteria, accounts substantially for the patterns of bacterial species specificity in bioluminescent symbiosis.

\section{Experimental procedures}

\section{Collection of fish specimens and isolation of bacterial strains}

Samples of fresh marine fishes were purchased from local retail markets in Ann Arbor, MI. The kind of fish and its place of capture, to the extent related by the retailer, are listed in Table 1. Luminous bacteria were isolated from the skin of these fishes by incubation of the samples at low temperature (Beijerinck, 1889, 1916; Nealson, 1978; Baumann and Baumann, 1981). Specifically, each sample of flank, head or tail, with skin intact, was placed in a sterile tray, partially covered with sterile artificial seawater (Nealson, 1978; Baumann and Baumann, 1981), and incubated for $1-6$ days at $6-8^{\circ} \mathrm{C}$. The samples were observed daily in a darkened room, and luminous spots appearing on the surface of the skin, indicative of the growth of luminous bacteria, were picked and streaked for isolated colonies on plates of LSW-70 agar (Dunlap and Ast, 2005), which contained per litre $10 \mathrm{~g}$ tryptone, $5 \mathrm{~g}$ yeast extract, $350 \mathrm{ml}$ double-strength artificial seawater (Nealson, 1978), $650 \mathrm{ml}$ de-ionized water and $15 \mathrm{~g}$ agar; plates were incubated at $18-22^{\circ} \mathrm{C}$. Luminous colonies were then purified by streaking on LSW-70 agar and stored at $-75^{\circ} \mathrm{C}$ in cryoprotective medium (Dunlap and Kita-Tsukamoto, 2001). Fish skin isolates were numbered to indicate the fish sample and strain; e.g. FS-1.2 designates strain number two from fish skin sample number one.
Specimens of deep-sea fishes (Tables 1 and 2) were collected at Owase City Fish Market, Mie Prefecture, and at Odawara City Fish Market, Kanagawa Prefecture, Honshu, Japan. Chlorophthalmid, macrourid and morid fishes were captured by trawl netting at a depth of $350 \mathrm{~m}$ in the Kumano Sea approximately $40 \mathrm{~km}$ east of Owase, Mie Prefecture, Honshu, Japan (landed at Owase). Other morids were taken by hand line offshore near Odawara, and at Choshi, Chiba Prefecture (landed at Odawara). Trachichthyids were taken by trap net at Fukuura, near Manazuru, Kanagawa Prefecture (landed at Odawara). Fishes were identified to species by reference to the study by Nakabo (2002), and ichthyological nomenclature follows the study by Nelson (1994). Fish specimens were kept chilled on ice until sampled. Luminous bacteria were isolated from the light organs of these fishes essentially as previously described (Dunlap and Ast, 2005). The light organ was aseptically dissected from the fish and homogenized in $0.5 \mathrm{ml}$ or $1.0 \mathrm{ml}$ of sterile artificial $70 \%$ seawater containing $25 \mathrm{mM}$ HEPES buffer ( $\mathrm{pH} 7.25$ ) (BSW-70) in a sterile hand-held Ten Broeck tissue homogenizer (Dunlap, 1985). The light organ homogenate was then serially diluted in BSW-70, and 25-100 $\mu$ l portions of one or more of the dilutions were spread on plates of LSW-70 agar. Isolated luminous colonies were picked at random after $24-48 \mathrm{~h}$ of incubation at $18-22^{\circ} \mathrm{C}$ and purified and stored as described above. Strain designations for light-organ isolates indicate the species and specimen number of the host fish and strain number (Dunlap et al., 2004); e.g. ckamo.1.2 designates strain number two from specimen number one of Caelorinchus kamoharai.

\section{Origin of P. phosphoreum ATCC $11040^{T}$}

Through assistance provided by $M$. Figge of the Netherlands Culture Collection of Bacteria (NCCB), L. Robertson of the Kluyver Laboratory for Biotechnology at Delft University of Technology and staff of the American Type Culture Collection (ATCC), we traced the origin and history of the type strain of P.phosphoreum, ATCC $11040^{\top}$. Records of the NCCB indicate that ATCC $11040^{\top}$ was isolated by J. C. Hoogerheide, a student of A. J. Kluyver, in June 1934, from a fish, and was deposited by him in the strain collection of Kluyver's laboratory, the Laboratorium voor Microbiologie of the Technische Hoogeschool at Delft (LMD), as LMD 34.28. We surmise, because specifics are lacking from the strain record, that the fish was taken from waters of the North Sea and that the strain was isolated from the surface of the fish, in the manner of earlier studies of luminous bacteria at Delft by Kluyver's predecessor, M. W. Beijerinck (1889, 1916), the method used in this study. ATCC records indicate that F. H. Johnson of Princeton University deposited this strain, received from Kluyver, with the ATCC in 1951, and provided a replacement in 1959 from his strain stocks. Johnson apparently received LMD 34.28 during his visit in 1939 to Kluyver's group at Delft and Utrecht (Johnson, 1939), where he worked under the supervision of van Schouwenberg (1938). For example, Johnson cites provision to him of a strain of $P$. phosphoreum by Kluyver from 'the Delft Collection' in 1939 (Johnson et al., 1943, 1945; Johnson and Gray, 1949). More recent information indicates that LMD 34.28 was lost from the LMD but was 
replaced in 1980 by NCIMB $1282\left(=\right.$ ATCC $\left.11040^{\top}\right)$ from the National Collections of Industrial, Food and Marine Bacteria (NCIMB), which received it, as ATCC $11040^{\top}$, from the ATCC; the LMD listed this replacement strain as LMD 34.28a (neotype) (= LMD 80.93). Transition of the LMD collection to the NCCB in 1998 has led to a re-numbering of strains, and this strain now carries the new number, NCCB 80093.

\section{$16 S$ rRNA, gyrB and luxABFE gene amplification and sequencing}

Genomic DNA was purified from $1 \mathrm{ml}$ cultures of strains grown overnight in LSW-70 broth using the Qiagen (Valencia, California) DNeasy tissue extraction kit. The 16S rRNA gene (approximately 1500 nucleotides) was amplified using the primers $27 f$ and $1492 r$ (Lane, 1991) and previously described PCR methods (Ast and Dunlap, 2004; Dunlap and Ast, 2005), and the product was sequenced using the amplification primers and the internal primers $772 \mathrm{r}$ and $669 \mathrm{f}$ (Dunlap et al., 2004). For amplification of gyrB (approximately 1200 nucletotides), the 16S rRNA gene protocol was followed except that the primers $22 f$ and 1240r (Ast and Dunlap, 2004) were used, and primer annealing was at $48^{\circ} \mathrm{C}$. The gyrB product was sequenced using the amplification primers. Primers and the protocol designed for amplification of the luxABFE region (approximately 2800 nucleotides) from P.phosphoreum strains (Ast and Dunlap, 2004) were used for amplification of this region from all strains. The entire region, luxABFE, was amplified using the primers Af and FEr (Ast and Dunlap, 2004), and the luxA and luxFE fragments of this product were sequenced using the amplification primers and the internal primers AseqR (5'-TCWGAYCCATTTGCTTCGAAACCAA GG-3') and FseqF (5'-ATGAATAATGCRTTAGAAACATTA CGYAT) respectively. The luxAB fragment of the luxABFE product was amplified and sequenced for strains from morid and macrourid fishes using the primers $A B s e q F$ (5'-AAACGTCGAGTTGACTATAGCCACGAT-3') and ABseqR (5'-GCTCCAACGATATGTCAGTGGCAGC-3'), whereas it was amplified and sequenced for strains from chlorophthalmid fishes and from the skin of fishes using the primer pair $\mathrm{ABf} / \mathrm{ABr}$ (Ast and Dunlap, 2004). For all strains, the luxBF fragment was amplified and sequenced using the primer pair Bf/Fr (Ast and Dunlap, 2004). Sequencing of PCR products was carried out by staff of the University of Michigan Sequencing Core using dye terminator cycle sequencing on a Perkin-Elmer ABI 3730.

Attempts to amplify luxA from strains of $P$. iliopiscarium used the general luxA primer pair and the following protocol of Wimpee and colleagues (1991): initial denaturing at $95^{\circ} \mathrm{C}$ for $2 \mathrm{~min}$; five cycles of denaturing at $94^{\circ} \mathrm{C}$ for $1.5 \mathrm{~min}$, annealing at $37^{\circ} \mathrm{C}$ for $20 \mathrm{~s}$, extension at $72^{\circ} \mathrm{C}$ for $2 \mathrm{~min} ; 25$ cycles of denaturing at $94^{\circ} \mathrm{C}$ for $1.5 \mathrm{~min}$, annealing at $55^{\circ} \mathrm{C}$ for $20 \mathrm{~s}$, extension at $72^{\circ} \mathrm{C}$ for $2 \mathrm{~min}$; one cycle at $72^{\circ} \mathrm{C}$ for $7 \mathrm{~min}$; snap cooling to $4^{\circ} \mathrm{C}$. Also tested with this protocol were the Af/Ar primer pairs specific for luxA from P. phosphoreum, P. leiognathi and P. fischeri (Ast and Dunlap, 2004). A second, more relaxed protocol to test for the presence of luxA used an annealing temperature of $35^{\circ} \mathrm{C}$ for 35 cycles with the general IUXA primer pair and with the P.phosphoreumspecific Af/Ar primer pair.

\section{Phylogenetic analysis}

16S rRNA gene sequences were aligned by eye, and gyrB and IUXABFE sequences were aligned by inferred amino acid sequence. Simultaneous parsimony analysis of the 16S rRNA, gyrB and luxABFE gene sequences (approximately 5500 nucleotides) was performed using PAUP* portable version (Swofford, 2002), using 1000 heuristic replicates with TBR swapping, collapsing zero-length branches, and treating ambiguous nucleotides as polymorphic rather than uncertain (ambiguous nucleotides were found only in 16S rRNA gene sequences and result from multiple copies of $r$ operons in this group). Jackknife values were calculated with PAUP* using 455 replicates emulating Jac re-sampling ( $360 \mathrm{~h}$ of processor time on a Macintosh PowerPC $2.5 \mathrm{GHz}$ G5 processor with 4 GB RAM running natively in OS X); AK-1 and AK-9 were omitted from jackknife re-sampling analysis because limited sequence data were available for them. Bremer support values were calculated with the aid of TreeRot (Sorenson, 1999), once with AK-1 and AK-9 included and once with them excluded (Fig. 1, values in parentheses), which reduced the number of most parsimonious trees from 2688 to 144 . Bremer support values were substantially improved by the exclusion of these two strains.

\section{GenBank accession}

GenBank accession numbers for sequences obtained in this study are as follows: 16S rRNA gene sequences, AY849395AY849433, AY888009-AY888020 and AY900628; gyrB sequences, AY849434-AY849481, AY8880021-AY888023 and AY900627; luxABFE sequences, AY849482-AY849528. Non-luxA PCR products obtained with luxA primers for the strains ATCC $51760^{\top}$ and NCIMB 13476 (Fig. 2) are AY888007 and AY888008 respectively. The accession numbers for the genes of the remaining 13 Photobacterium strains used in this analysis are listed in the studies by Dunlap and colleagues (2004), Ast and Dunlap (2004) and Dunlap and Ast (2005); for lux and 16S rRNA gene sequences of strains AK-1 and AK-9, see the study by Budsberg and colleagues (2003).

\section{Acknowledgements}

We thank A. Makihara, captain of the fishing vessel Kotobukimaru, and K. Yamahashi, Odawara City Fish Market, for generously providing many of the fish specimens used in this study. Acquisition of these specimens was kindly facilitated by S. Kimura, Fisheries Research Laboratory, Mie University, Shima, Japan, A. Iwata, Mie Prefecture Office, Owase, Japan and $\mathrm{H}$. Senou, Kanagawa Prefectural Museum of Natural History, Odawara, Japan. S. Kimura provided guidance on fish identifications. We thank $\mathrm{C}$. Wimpee for providing the AK strains. The staff of the Whole Foods Market, Ann Arbor, MI, provided information on the places of capture of retail fish market specimens, and C. Wimpee, K. Budsberg and D. Georgala provided information on the ecological sources of certain bacterial strains. We thank J. Young, NCIMB, for providing deposition date for strains NCIMB 66 and NCIMB 12839, and M. Figge, L. Robertson and staff of the ATCC for providing historical information. DNA sequencing was carried 
out by staff of the University of Michigan Sequencing Core. Support was provided by NSF Grant DEB 0413441.

\section{References}

Ast, J.C., and Dunlap, P.V. (2004) Phylogenetic analysis of the lux operon distinguishes two evolutionarily distinct clades of Photobacterium leiognathi. Arch Microbiol 181: 352-361.

Bartlett, D.H., Wright, M., Yayanos, A.A., and Silverman, M. (1989) Isolation of a gene regulated by hydrostatic pressure in a deep-sea bacterium. Nature 342: 572-574.

Baumann, P., and Baumann, L. (1981) The marine Gramnegative eubacteria: genera Photobacterium, Beneckea, Alteromonas, Pseudomonas, and Alcaligenes. In The Prokaryotes: A Handbook on Habitats, Isolation, and Identification of Bacteria. Starr, M.P., Stolp, H., Trüper, H.G., Balows, A., and Schlegel, H.G. (eds). Berlin, Gemany: Springer-Verlag, pp. 1302-1331.

Baumann, P., and Baumann, L. (1984) Genus II Photobacterium Beijerinck 1889, 401 ${ }^{\mathrm{AL}}$. In Bergey's Manual of Systematic Bacteriology, Vol. 1. Kreig, N.R., and Holt, J.G. (eds). Baltimore, USA: Williams and Wilkins, pp. 539-545.

Beijerinck, M.W. (1889) Photobacterium luminosum, a luminous bacterium from the North Sea (Le Photobacterium luminosum, Bactérie lumineuse de la Mer du Nord). Translated from Archives Néerlandaises des Sciences Exactes et Naturelles, 23: 401-427. (Gradsten, M.A., and Lichtfield, C.D., transl.). In Marine Microbiology. Lichtfield, C.D. (ed.). Stroudberg, USA: Dowden, Hutchinson and Ross, pp. 1625.

Beijerinck, M.W. (1916) Die Leuchtbakterien der Nordsee im August und September. Folia Microbiologica 4: 15-40.

Boisvert, H., Chatelain, R., and Bassot, J.M. (1967) Étude d'un Photobacterium isolé de l'organe lumineux des poissons Leiognathidae. Ann Inst Pasteur (Paris) 112: 520524.

Budsberg, K.J., Wimpee, C.F., and Braddock, J.F. (2003) Isolation and identification of Photobacterium phosphoreum from an unexpected niche: migrating salmon. Appl Environ Microbiol 69: 6938-6942.

Cohn, F. (1878) Versameling van stucken betreffende het geneeskundig staats toerzich, 126-130. (Letter to J. Penn describing Micrococcus phosphoreum). Citation quoted from Euzeby (2005).

Dalgaard, P., Barlett, D.H., and Haygood, M.G. (1999) Photobacterium phosphoreum - identification and detection of luminous and non-luminous isolates from seafood and natural marine habitats. In Food Microbiology and Food Safety into the Next Millennium. Proceedings of the 17th International Conference on Food Microbiology and Safety. Tuijtelaars, A.C.J., Samson, R.A., Rombouts, F.M., and Notermans, S. (eds). Veldhoven, the Netherlands: Foundation for Food Microbiology, pp. 160-164.

Dalgaard, P., Gram, L., and Huss, H.H. (1993) Spoilage and shelf life of cod fillets packed in vacuum or modified atmospheres. Int J Food Microbiol 19: 283-294.

Dalgaard, P., Manio, G.P., and Goodfellow, M. (1997) Classification of photobacteria associated with spoilage of fish products by numerical taxonomy and pyrolysis mass spectrometry. Zbl Bakt 285: 157-168.
Dunlap, P.V. (1984) The ecology and physiology of the light organ symbiosis between Photobacterium leiognathi and ponyfishes. PhD dissertation. Los Angeles, USA: UCLA.

Dunlap, P.V. (1985) Physiological and morphological state of the symbiotic bacteria from light organs of ponyfish. Biol Bull 167: 410-425.

Dunlap, P.V. (2004) Phylogenetic analysis refutes symbionthost co-speciation in bioluminescent symbiosis. Cladistics (p. 592. Abstracts of the 23rd Annual Meeting of the Willi Hennig Society, Paris).

Dunlap, P.V., and Ast, J.C. (2005) Genomic and phylogenetic characterization of the luminous bacteria symbiotic with the deep-sea fish Chlorophthalmus albatrossis (Aulopiformes: Chlorophthalmidae). Appl Environ Microbiol 71: 930-939.

Dunlap, P.V., and Kita-Tsukamoto, K. (2001) Luminous bacteria. In The Prokaryotes, an Evolving Electronic Resource for the Microbiological Community. (chapt. 328) Dworkin, M., Falkow, S., Rosenberg, E., Schleifer, K.-H., and Stackebrandt, E. (eds). New York, USA: Academic Press.

Dunlap, P.V., Jiemjit, A., Ast, J.C., Pearce, M.M., Marques, R.R., and Lavilla-Pitogo, C.R. (2004) Genomic polymorphism in symbiotic populations of Photobacterium leiognathi. Environ Microbiol 6: 145-158.

Euzeby, J.P. (2005) List of bacterial names with standing in nomenclature. [WWW document]. URL http:// www.bacterio.net

Fidopiastis, P.M., Sorum, H., and Ruby, E.G. (1999) Cryptic luminescence in the cold-water fish pathogen Vibrio salmonicida. Arch Microbiol 171: 205-209.

Flodgaard, L.R., Dalgaard, P., Andersen, J.B., Nielsen, K.F., Givskov, M., and Gram, L. (2005) Nonbioluminescent strains of Photobacterium phosphoreum produce the cell-to-cell communication signal $\mathrm{N}$-(3-hydroxyoctanoyl) homoserine lactone. Appl Environ Microbiol 71: 21132120.

Fox, G.E., Wisotzkey, J.D., and Jurtshuk, P., Jr. (1992) How close is close: $16 \mathrm{~S}$ rRNA sequence identity may not be sufficient to guarantee species identity. Int J Sys Bacteriol 42: $166-170$.

Gauthier, G., Lafay, B., Ruimy, R., Breittmayer, V., Nicolas, J.L., Gauthier, M., and Christen, R. (1995) Small-subunit rRNA sequences and whole DNA relatedness concur for the reassignment of Pasteurella piscicida (Snieszko et al.) Janssen and Surgalla to the genus Photobacterium as Photobacterium damsela subsp. piscicida. Int J Syst Bacteriol 45: 139-144.

Georgala, D.L. (1958) The bacterial flora of the skin of North Sea cod. J Gen Microbiol 18: 84-91.

Graybeal, A. (1998) Is it better to add taxa or characters to a difficult phylogenetic problem? Syst Biol 47: 9-17.

Haneda, Y. (1951) The luminescence of some deep-sea fishes of the families Gadidae and Macrouridae. Pacific Sci 5: 372-378.

Haneda, Y. (1957) Observations on luminescence in the deep sea fish, Paratrachichthys prosthemius. Sci Rep Yokosuka City Mus 2: 15-23.

Haneda, Y., and Yoshiba, S. (1970) On a luminous substance of the anacanthine fish Steindachneria argentea from the Gulf of Mexico. Sci Rep Yokosuka City Mus 16: 1-4.

Hastings, J.W., and Nealson, K.H. (1981) The symbiotic lumi- 
nous bacteria. In The Prokaryotes: A Handbook on Habitats, Isolation, and Identification of Bacteria. Starr, M.P., Stolp, H., Trüper, H.G., Balows, A., and Schlegel, H.G. (eds). Berlin, Germany: Springer-Verlag, pp. 1332-1345.

Haygood, M.G. (1993) Light organ symbioses in fishes. Crit Rev Microbiol 19: 191-216.

Haygood, M.G., Distel, D.L., and Herring, P.J. (1992) Polymerase chain reaction and $16 \mathrm{~S}$ rRNA gene sequences from the luminous bacterial symbionts of two deep-sea anglerfishes. J Mar Biol Assoc UK 71: 149-159.

Hendrie, M.S., Hodgkiss, W., and Shewan, J.M. (1970) The identification, taxonomy and classification of luminous bacteria. J Gen Microbiol 64: 151-169.

Herring, P.J. (1975) Bacterial bioluminescence in some argentinoid fishes. In Proceedings of the 9th European Marine Biological Symposium. Barnes, H. (ed.). Aberdeen, UK: Aberdeen University Press. pp. 563-572.

Herring, P.J. (1982) Aspects of the bioluminescence of fishes. Oceanogr Mar Biol Ann Rev 20: 415-470.

Herring, P.J., and Morin, J.G. (1978) Bioluminescence in fishes. In Bioluminescence in Action, Herring, P.J. (ed.). London, UK: Academic Press, pp. 273-329.

Hillis, D.M. (1998) Taxonomic sampling, phylogenetic accuracy, and investigator bias. Syst Biol 47: 3-8.

Johnson, F.H. (1939) Total luminescence of bacterial suspensions in relation to the reactions concerned in luminescence. Enzymologia 8: 72-81.

Johnson, F.H., and Gray, D.H. (1949) Nuclei and large bodies of luminous bacteria in relation to salt concentration, osmotic pressure, temperature, and urethane. J Bacteriol 58: 675-688.

Johnson, F.H., Zworykin, N., and Warren, G. (1943) A study of luminous bacterial cells and cytolysates with the electron microscope. J Bacteriol 46: 167-184.

Johnson, F.H., Eyring, H., Steblay, R., Chaplin, H., Huber, C., and Gherardi, G. (1945) The nature and control of reactions in bioluminescence. J Gen Physiol 28: 463537.

Kishitani, T. (1930) Studien über die Leuchtsymbiose in Physiculus japonicus Hilgendorf, mit der Beilage der zwei neuen arten der Leuchtbacterien. Sci Rep Tohoku Univ 5: 801-823.

Kuwae, T., Fukasawa, S., Sasaki, T., and Kurata, M. (1982) Immunochemical comparisons among lipopolysaccharides from symbiotic luminous bacteria isolated from several luminous marine animals. Microbiol Immunol 26: 11811186.

Lane, D.J. (1991) 16S/23S rRNA sequencing. In Nucleic Acid Techniques in Bacterial Systematics. Stackebrandt, E., and Goodfellow, M. (eds). New York, USA: John Wiley and Sons, pp. 115-175.

Nakabo, T. (ed.) (2002) Fishes of Japan with Pictoral Keys to the Species. Tokyo, Japan: Tokai University Press.

Nealson, K.H. (1978) Isolation, identification and manipulation of luminous bacteria. Meth Enzymol 57: 153-166.

Nealson, K.H., and Hastings, J.W. (1977) Low oxygen is optimal for luciferase synthesis in some bacteria. Arch Microbiol 112: 9-16.

Nelson, J.S. (1994) Fishes of the World, 3rd edn. New York, USA: John Wiley and Sons.

Nogi, Y., Masui, N., and Kato, C. (1998) Photobacterium profundum sp. nov., a new, moderately barophilic bacterial species isolated from a deep-sea sediment. Extremophiles 2: $1-7$.

Onarheim, A.M., and Raa, J. (1990) Characteristics and possible biological significance of an autochthonous flora in the intestinal mucosa of sea-water fish. In Microbiology in Poecilotherms. Lésel, R. (ed.). Amsterdam, the Netherlands: Elsevier, pp. 197-201.

Onarheim, A.M., Wiik, R., Burghardt, J., and Stackebrandt, E. (1994) Characterization and identification of two Vibrio species indigenous to the intestine of fish in cold sea water; description of Vibrio iliopiscarius sp. nov. System Appl Microbiol 17: 370-379.

Palmer, L.M., and Colwell, R.R. (1991) Detection of luciferase gene sequence in nonluminescent Vibrio cholerae by colony hybridization and polymerase chain reaction. Appl Environ Microbiol 57: 1286-1293.

Papke, R.T., Ramsing, N.B., Bateson, M.M., and Ward, D.M. (2003) Geographical isolation in hot spring cyanobacteria. Environ Microbiol 5: 650-659.

Reichelt, J.L., and Baumann, P. (1973) Taxonomy of the marine, luminous bacteria. Arch Mikrobiol 94: 283-330.

Reichelt, J.L., Baumann, P., and Baumann, L. (1976) Study of genetic relationships among marine species of the genera Beneckea and Photobacterium by means of in vitro DNA/DNA hybridization. Arch Microbiol 110: 101120.

Roselló-Mora, R., and Amann, R. (2001) The species concept for prokaryotes. FEMS Microbiol Rev 25: 39-67.

Ruby, E.G., and Morin, J.G. (1978) Specificity of symbiosis between deep-sea fish and psychrotrophic luminous bacteria. Deep-Sea Res 25: 161-171.

van Schouwenberg, K.L. (1938) On respiration and light emission in luminous bacteria. PhD dissertation. Delft, the Netherlands: Technische Hoogeschool te Delft.

Shimizu, T. (1997) Beryciformes. In Sea Fishes of Japan. Okamura, O., and Amaoka, K.K. (eds). Tokyo, Japan: Yama-Kei Publishers, pp. 156-167.

Singleton, R.J., and Skerman, T.M. (1973) A taxonomic study by computer analysis of marine bacteria from New Zealand waters. J Roy Soc New Zealand 3: 129-140.

Skerman, V.B.D., McGowan, V., and Sneath, P.H.A. (eds) (1980) Approved lists of bacterial names. Int J Syst Bacteriol 30: 225-420.

Somiya, H. (1981) On the bacterial-associated light organ in Chlorophthalmus. In Bioluminescence and Chemiluminescence, Basic Chemistry and Analytical Applications. DeLuca, M.A., and McElroy, W.D. (eds). New York, USA: Academic Press, pp. 561-567.

Sorenson, M.D. (1999) TreeRot, Version 2. Boston, USA: Boston University.

Sparks, J.S., and Dunlap, P.V. (2004) A clade of non-sexually dimorphic ponyfishes (Teleostei: Perciformes: Leiognathidae): phylogeny, taxonomy, and description of a new species. Am Mus Novitates 3459: 1-21.

Staley, J.T. (1999) Bacterial biodiversity: a time for place. ASM News 65: 681-687.

Swofford, D.L. (2002) PAUP*: Phylogenetic Analysis Using Parsimony (*and Other Methods), Version 4.0B10. Sunderland, USA: Sinauer Associates.

Thompson, C.C., Thompson, F.L., Vandemeulebroecke, K., 
Hoste, B., Dawyndt, P., and Swings, J. (2004) Use of recA as an alternative phylogenetic marker in the family Vibrionaceae. Int J Syst Evol Microbiol 54: 919-924.

Urakawa, H., Kita-Tsukamoto, K., and Ohwada, K. (1999) Reassessment of the taxonomic position of Vibrio iliopiscarius (Onarheim et al. 1994) and proposal for Photobacterium iliopiscarium comb. nov. Int $J$ Syst Bacteriol 49: 257-260.

Vinuesa, P., Silva, C., Werner, D., and Martinez-Romero, E. (2005) Population genetics and phylogenetic inference in bacterial molecular systematics: the roles of migration and recombination in Bradyrhizobium species cohesion and delination. Molec Phylogenet Evol 34: 29-54.

Vydryakova, G.A., Kuznetsov, A.M., Primakova, G.A., Chugaeva, Y.V., and Fish, A.M. (1995) Luminescent bacterial symbionts and commensals of luminescent and non- luminescent animals of the Indian Ocean. Microbiology 64: 589-592.

Whitaker, R.J., Grogan, D.W., and Taylor, J.W. (2003) Geographic barriers isolate endemic populations of hyperthermophilic Archaea. Science 301: 976-978.

Wimpee, C.F., Nadeau, T.-L., and Nealson, K.H. (1991) Development of species-specific hybridization probes for marine luminous bacteria using in vitro DNA amplification. Appl Environ Microbiol 57: 1319-1324.

Yasaki, Y., and Haneda, Y. (1935) On the luminescence of the deep-sea fishes, family macrouridae. Oyo-Dobustugaku Zasshi (Jap J Appl Zool) 7: 165-177.

Yasaki, Y., Nishio, M., Ichikawa, A., Magima, R., and Ishikawa, O. (1926) Bacteriological studies on bioluminescence. II. On the nature of the new luminous bacteria, Microspira phosphoreum Yasaki. Sei-I-Kwai Med J 45(3). 